\title{
DETERMINAN PERSEPSI WAJIB PAJAK BADAN MENGENAI ETIKA PENGGELAPAN PAJAK (STUDI PADA WAJIB PAJAK BADAN YANG TERDAFTAR DI KANTOR PELAYANAN PAJAK PRATAMA PURWAKARTA)
}

\author{
Oleh : \\ Rivani Aulia Haq, Ayu Fury Puspita \\ Program Studi Akuntansi - Universitas Brawijaya Malang \\ rivaniauliahaq@gmail.com
}

\begin{tabular}{|c|c|}
\hline Article Info & Abstract \\
\hline Article History: & This aim of this study is to determine corporate taxpayers' \\
\hline Received. & perceptions on the ethics of tax evasion. This research was \\
\hline Accepted & conducted at the Small Tax Office of Purwakarta. This study \\
\hline Available Online & used primary data obtained through questionnaires \\
\hline & submitted by corporate tax payers registered at the Small \\
\hline & Tax Office of Purwakarta. The sampling method used in this \\
\hline & study was convenience sampling. Hypothesis testing was \\
\hline & $\begin{array}{l}\text { conducted by the Partial Least Square (PLS) statistical } \\
\text { method with the help of the SmartPLS program. Based on }\end{array}$ \\
\hline & $\begin{array}{l}\text { methoa with the help of the Smart } \mathrm{S} \text { program. Basea on } \\
\text { correlation analysis, it was found that taxpayer compliance }\end{array}$ \\
\hline & is at a low level (0.254673) and tax system is also at a low \\
\hline & level (0.366459). Hypothesis testing found that $H_{0}$ rejected \\
\hline & and $H_{a}$ is accepted; this means that there is a relationship \\
\hline & $\begin{array}{l}\text { between taxpayer compliance and tax system, regarding } \\
\text { corporate taxpayers' perceptions on the ethics of tax } \\
\text { evasion. }\end{array}$ \\
\hline
\end{tabular}

Keyword:

Tax Justice, Discrimination,

Taxpayer Compliance,

Tax Examination,

Taxation System, Tax Evasion,

Signal Theory..

\section{PENDAHULUAN}

Penggelapan pajak merupakan suatu tindakan yang dilakukan oleh wajib pajak agar pajak terutang yang dibayar dapat diperkecil dengan cara melanggar ketentuan perpajakan. Penggelapan pajak masuk ke dalam tindak pidana perpajakan karena wajib pajak berusaha untuk melanggar hukum dan sengaja tidak melapor objek pajak secara lengkap dan benar (Fatimah, 2017). Beberapa tindakan yang dapat dikategorikan sebagai tindak pidana perpajakan antara lain tidak melapor Surat Pemberitahuan (SPT), melapor SPT secara tidak lengkap maupun tidak benar, tidak menyetorkan pajak yang telah dipotong, serta menerbitkan faktur pajak yang tidak sesuai dengan transaksi yang sebenarnya (www.pajak.go.id, 2013).

Pada dasarnya penggelapan pajak terjadi karena terdapat perbedaan kepentingan antara perusahaan dengan pemerintah. Bagi perusahaan, pajak penghasilan yang dikenakan atas penghasilan yang diperoleh dan/atau diterima, dapat saja dianggap sebagai biaya atau beban dalam menjalankan usaha (Suandy, 2011:5), sedangkan bagi pemerintah, pajak merupakan sumber penerimaan negara yang sangat penting yang diperuntukkan untuk 
pengeluaran-pengeluaran negara. Salah satu indikasi terjadi penggelapan pajak dapat dilihat melalui pencapaian target penerimaan pajak yang kurang terutama di KPP Pratama Purwakarta. Dalam lima tahun terakhir, realisasi penerimaan pajak di KPP Pratama Purwakarta belum mencapai target yang ditetapkan. Berikut data mengenai realisasi penerimaan pajak di KPP Pratama Purwakarta dapat dilihat dalam Lampiran 1 di bawah ini:

Berdasarkan lampiran 1, realisasi penerimaan pajak di KPP Pratama Purwakarta belum mencapai target yang telah ditetapkan, hanya pada tahun 2014 mendekati target penerimaan pajak dengan presentase penerimaan pajak sebesar 97\%. Kedua, penyampaian SPT Tahunan di KPP Pratama Purwakarta masih tergolong rendah. Berikut data mengenai penyampaian SPT Tahunan di KPP Pratama Purwakarta dapat dilihat dalam Tabel 1.2 di bawah ini:

Tabel 1.2

Kepatuhan Wajib Pajak Badan di KPP Pratama Purwakarta

\begin{tabular}{|c|c|c|c|}
\hline Tahun & $\begin{array}{c}\text { WP } \\
\text { Badan } \\
\text { Wajib } \\
\text { SPT }\end{array}$ & $\begin{array}{c}\text { Realisasi } \\
\text { SPT } \\
\text { Tahunan }\end{array}$ & $\begin{array}{c}\% \\
\text { Kepatuhan }\end{array}$ \\
\hline 2013 & 2,793 & 1,103 & $39 \%$ \\
\hline 2014 & 2,775 & 1,057 & $38 \%$ \\
\hline 2015 & 2,983 & 1,857 & $62 \%$ \\
\hline 2016 & 3,351 & 1,843 & $55 \%$ \\
\hline 2017 & 3,196 & 1,683 & $53 \%$ \\
\hline
\end{tabular}

Sumber: Bagian PDI KPP Pratama Purwakarta Berdasarkan Tabel 1.2, kepatuhan wajib pajak badan dalam menyampaikan SPT Tahunan di KPP Pratama Purwakarta mengalami fluktuasi, hanya pada tahun 2015 presentase kepatuhan wajib pajak meningkat sebesar $62 \%$. Ketidaktercapaian terget penerimaan pajak dan kepatuhan wajib pajak badan yang rendah, mengindikasikan masih terdapat masalah perpajakan, salah satunya disebabkan oleh perilaku penghindaran pajak atau bahkan penggelapan pajak (Suminarsasi, 2011). Kesadaran wajib pajak badan yang rendah dalam membayar pajak, akan berdampak pada sistem pemungutan pajak yang berlaku.

Sistem pemungutan pajak yang berlaku merupakan elemen penting dalam penunjangan keberhasilan pemungutan pajak di suatu negara. Di Indonesia sistem pemungutan pajak adalah self assessment system, di mana wajib pajak mempunyai peran aktif dalam menghitung, membayar, dan melapor sendiri pajak terutang. Fiskus hanya bertugas untuk mengawasi pelaksanaan dengan melakukan pemeriksaan secara rutin terhadap peraturan perpajakan yang berlaku. Dengan sistem pemungutan pajak yang berlaku, wajib pajak mempunyai kewajiban untuk jujur, sadar, dan disiplin dalam melaksanakan kewajiban perpajakan, tetapi justru self assessment system dapat menciptakan peluang wajib pajak untuk melakukan penggelapan pajak, karena wajib pajak diberi wewenang dan tanggungjawab yang penuh untuk melaksanakan kewajiban perpajakan.

Menurut Putri (2017) penggelapan pajak merupakan perilaku yang tidak beretika. Karena etika berkaitan erat dengan moral, moral untuk melakukan perbuatan baik dan menghindari tindakan yang tercela. Namun, pada kondisi tertentu penggelapan pajak dapat dianggap sebagai perilaku yang etis. Menurut McGee (2005) penggelapan pajak dianggap sebagai suatu perilaku yang etis dikarenakan beberapa hal, yaitu tidak terdapat keadilan dari uang yang berasal dari pajak, korupsi yang dilakukan pemerintah, dan tidak merasakan manfaat atas pajak yang dibayarkan. Menurut Rahman (2013) penggelapan pajak dianggap menjadi perbuatan yang etis dikarenakan birokrasi pemerintah yang kurang baik sehingga akan menimbulkan persepsi wajib pajak yang akan cenderung untuk tidak patuh dalam kewajiban perpajakan.

Penelitian ini mengacu pada penelitian yang dilakukan oleh Zuliyanti (2017) dengan menggunakan variabel yang sama yaitu keadilan pajak, diskriminasi, kepatuhan wajib pajak, pemeriksaan pajak, dan sistem perpajakan. Adapun perbedaan dengan penelitian sebelumnya yaitu di mana sampel yang digunakan dalam penelitian ini adalah wajib pajak badan yang terdaftar di KPP Pratama Purwakarta sedangkan penelitian sebelumnya adalah wajib pajak badan yang terdaftar di KPP Pratama Surabaya. Penelitian ini dilakukan di tahun 2018 karena pada kondisi di tahun 2017 ada ketidaksinkronan antara kepatuhan wajib pajak dalam membayar pajak dan melapor SPT Tahunan.

Dari berbagai uraian di atas, rumusan masalah dalam penelitian ini adalah sebagai berikut: 
1. Apakah keadilan pajak berpengaruh positif terhadap persepsi wajib pajak badan mengenai etika penggelapan pajak?

2. Apakah diskriminasi berpengaruh positif terhadap persepsi wajib pajak badan mengenai etika penggelapan pajak?

3. Apakah kepatuhan wajib pajak berpengaruh negatif terhadap persepsi wajib pajak badan mengenai etika penggelapan pajak?

4. Apakah pemeriksaan pajak berpengaruh negatif terhadap persepsi wajib pajak badan mengenai etika penggelapan pajak?

5. Apakah sistem perpajakan berpengaruh negatif terhadap persepsi wajib pajak badan mengenai etika penggelapan pajak?

\section{KAJIAN PUSTAKA DAN PEGEMBANGAN HIPOTESIS \\ Definisi Pajak}

Definisi pajak menurut Undang-Undang Nomor 16 Tahun 2009 Pasal 1 tentang ketentuan umum dan tata cara perpajakan, Pajak merupakan kontribusi wajib kepada negara yang terutang oleh orang pribadi atau badan yang bersifat memaksa berdasarkan undang-undang, dengan tidak mendapatkan imbalan secara langsung dan digunakan untuk kebutuhan negara juga kemakmuran rakyat.

\section{Pajak Penghasilan}

Pajak penghasilan $(\mathrm{PPh})$ merupakan pajak yang dibebankan kepada wajib pajak baik orang pribadi, perusahaan, ataupun badan hukum atas penghasilan yang diperoleh selama tahun pajak. Pajak penghasilan termasuk kedalam jenis pajak langsung di mana beban pajak ditanggung sendiri oleh wajib pajak dan tidak dapat diambilalih oleh orang lain. Dalam hal pelunasan $\mathrm{PPh}$ dapat dilakukan oleh wajib pajak dengan dua cara yaitu pelunasan $\mathrm{PPh}$ dalam tahun berjalan (angsuran) dan pelunasan $\mathrm{PPh}$ dalam akhir tahun pajak. Pelunasan $\mathrm{PPh}$ yang dalam tahun pajak berjalan merupakan pelunasan atau pembayaran atas perkiraan PPh yang akan terutang dalam suatu tahun pajak, sedangkan pelunasan pajak dalam tahun pajak berjalan dilakukan oleh wajib pajak melalui pemotongan dan pemungutan pajak oleh pihak lain maupun pembayaran pajak oleh wajib pajak itu sendiri.

\section{Persepsi}

Menurut Robbins (2015:88) persepsi merupakan proses di mana individu mengatur dan menafsirkan lingkungan di sekitar guna memberikan arti bagi lingkungan sekitar.
Rachmadi (2014) mendefinisikan persepsi sebagai respon dari penerimaan kesan melalui penglihatan, sentuhan, atau melalui indera lainnya, yang kemudian ditafsirkan berdasarkan pengalaman yang berbeda dari tiap individu, sehingga menghasilkan perilaku yang berbeda pula. Menurut Prasetyo (2010) Persepsi merupakan pandangan pikiran seseorang yang muncul dari kegiatan menafsirkan, mengalami, dan mengelola atas segala sesuatu yang terjadi di lingkungan sekitar.

\section{Etika}

Menurut Abrahams (2016) Istilah etika sangat berhubungan dengan tata krama, sopan santun, penalaran moral, norma susila, dan lainlain yang mana berhubungan juga dengan norma-norma yang ada di dalam masyarakat. Menurut Bertens (2000:32) etika merupakan nilai dan norma moral yang menjadi acuan bagi manusia secara individu maupun kelompok dalam mengatur tingkah laku. Menurut Silaen (2015) etika adalah kebiasaan hidup yang baik timbul dari diri seseorang maupun pada suatu masyarakat atau berkelompok dan menghindari hal-hal yang menimbulkan tindakan yang buruk.

Etika memiliki beragam makna yang berbeda-beda, dalam istilah akuntansi etika mengacu pada aturan yang mengatur tindakan profesional akuntan. Etika adalah kajian moralitas, yang berarti etika berkaitan dengan moralitas. Menurut Suminarsasi \& Supriyadi (2011) etika adalah semacam penelaahan (baik aktivitas penelahaan maupun hasil-hasil penelahaan itu sendiri) sedangkan moralitas merupakan pedoman yang dimiliki individu atau kelompok mengenai apa itu benar atau salah, atau baik dan jahat. Ketika etika dikaitkan dengan perpajakan, maka banyak pihak yang terlibat, salah satunya fiskus. Fiskus merupakan pihak yang sangat bertanggungjawab agar kasus-kasus penggelapan pajak yang ada di Indonesia menurun. Fiskus harus berperan aktif dalam mengawasi, membimbing, dan mengarahkan wajib pajak dalam melaksanakan kewajiban perpajakan sesuai dengan peraturan perpajakan.

Banyaknya fenomena penggelapan pajak yang sering terjadi, dikarenakan beberapa faktor yang mempengaruhi yaitu kinerja fiskus yang kurang maksimal, penegakkan hukum yang lemah membuat wajib pajak cenderung berani untuk melakukan tindakan penggelapan pajak, diskriminasi yang dirasakan oleh wajib 
pajak, dan kesadaran wajib pajak yang rendah untuk melaksanakan kewajiban perpajakan.

\section{Penggelapan Pajak}

Menurut Rahayu (2013:6) penggelapan pajak merupakan suatu tindakan untuk meminimalkan beban pajak dengan melawan ketentuan pajak (ilegal) yang dapat dihukum dengan sanksi pidana. Menurut Suminarsasi \& Supriyadi (2011) Penggelapan pajak merupakan usaha aktif wajib pajak dalam hal mengurangi, menghapus, manipulasi ilegal terhadap utang pajak atau meloloskan diri untuk tidak membayar pajak sebagaimana yang telah terutang menurut aturan perundangundangan. Penggelapan pajak mengacu pada tindakan yang tidak benar yang dilakukan oleh wajib pajak mengenai kewajiban perpajakan. Menurut Suandy (2016:2) ada beberapa faktor yang memotivasi wajib pajak untuk melakukan penggelapan pajak adalah sebagai berikut:

1. Jumlah pajak yang harus dibayar. Semakin besar pajak yang harus dibayar, semakin besar pula kecenderungan wajib pajak untuk melakukan pelanggaran.

2. Semakin kecil biaya untuk menyuap fiskus, semakin besar kecenderungan wajib pajak untuk melakukan pelanggaran.

3. Semakin kecil kemungkinan suatu pelanggaran terdeteksi, semakin besar kecenderungan wajib pajak untuk melakukan pelanggaran.

4. Semakin ringan sanksi yang dikenakan terhadap pelanggaran, semakin besar kecenderungan wajib pajak untuk melakukan pelanggaran.

Dari beberapa definisi tersebut dapat disimpulkan bahwa penggelapan pajak merupakan tindakan yang dilakukan oleh wajib pajak agar dapat memperkecil jumlah pajak yang dibayar dengan cara melanggar hukum. Penggelapan pajak termasuk kedalam tindak pidana perpajakan karena wajib pajak berusaha untuk melawan hukum dan sengaja tidak melaporkan objek pajak secara lengkap dan benar.

\section{Keadilan Pajak}

Mardiasmo (2013:4) mengungkapkan bahwa sesuai dengan tujuan hukum, yaitu mencapai keadilan, undang-undang dan pelaksanaan pemungutan harus adil. Adil dalam perundang-undangan antara lain mengenakan pajak secara umum dan merata, serta disesuaikan dengan kemampuan wajib pajak, sedangkan adil dalam pelaksanaan perpajakan yaitu dengan memberikan hak kepada wajib pajak untuk mengajukan keberatan, penundaan dalam pembayaran, dan mengajukan banding kepada Manjelis Pertimbangan Pajak.

\section{Diskriminasi}

Berdasarkan Undang-Undang Nomor 39 tahun 1999 tentang Hak Asasi Manusia Pasal 1 ayat 3 , diskriminasi merupakan setiap pembatasan, pelecehan atau pengucilan yang langsung atau tidak langsung didasarkan perbedaan manusia atas dasar agama, suku, ras, etnik, kelompok, golongan, status sosial, status ekonomi, jenis kelamin, bahasa, dan keyakinan politik, yang berakibat pengangguran, penyimpanan atau penghapusan pengakuan, pelaksanaan atau pengunaan hak asasi manusia dan kebebasan dasar dalam kehidupan, baik individual maupun kolektif dalam bidang politik, ekonomi, hukum, sosial, budaya dan aspek kehidupan yang lain.

\section{Kepatuhan Wajib Pajak}

Kepatuhan perpajakan menurut Nurmatu (2005:148) dapat didefinisikan sebagai suatu keadaan di mana wajib pajak memenuhi dan melaksanakan semua kewajiban perpajakan sesuai dengan peraturan perundangundangan yang berlaku. Kepatuhan wajib pajak dikemukakan oleh Nowak (Rahayu, 2013, hal. 138) kepatuhan wajib pajak dapat tercermin dalam situasi di mana:

1. Wajib pajak paham atau berusaha untuk memahami semua ketentuan peraturan perundang-undangan perpajakan,

2. Mengisi formulir pajak dengan lengkap dan jelas,

3. Menghitung jumlah pajak yang terutang dengan benar,

4. Membayar pajak yang terutang tepat waktu.

Maka dapat disimpulkan bahwa kepatuhan perpajakan merupakan tindakan wajib pajak dalam pemenuhan kewajiban perpajakan sesuai dengan ketentuan peraturan perundang-undangan perpajakan yang berlaku di suatu negara.

\section{Pemeriksaan Pajak}

Pemeriksaan pajak menurut UndangUndang Nomor 16 Tahun 2009. Pemeriksaan pajak adalah serangkaian kegiatan menghimpun dan mengolah data, keterangan dan/atau bukti yang dilaksanakan secara objektif dan proporsional berdasarkan suatu standar pemeriksaan untuk menguji kepatuhan 
pemenuhan kewajiban perpajakan dan/atau untuk tujuan lain dalam rangka melaksanakan ketentuan peraturan perundang-undangan perpajakan.

\section{Sistem Perpajakan}

Menurut Ilyas (2015:36-39) Sistem pemungutan pajak di Indonesia dapat dibagi menjadi 3 (tiga) yaitu Official Assessment System, Self Assessment System, Dan Withholding Tax System.

1. Official Assessment System. Suatu sistem pemungutan pajak yang memberi wewenang kepada pemungut pajak (fiskus) untuk menentukan besaran pajak yang terutang. Dengan official assessment system wajib pajak bersifat pasif dan menunggu dikeluarkan surat ketetapan pajak oleh fiskus. Besaran pajak terutang wajib pajak baru diketahui setelah adanya Surat Ketetapan Pajak (SKP).

2. Self Assessment System . Suatu sistem pemungutan pjaak yang memberi wewenang penuh kepada wajib pajak untuk menghitung, menyetor, dan melapor sendiri besaran pajak terutang. Sehingga melalui self assessment system administrasi perpajakan diharapkan dapat dilaksanakan dengan lebih rapi, terkendali, sederhana, dan mudah dipahami oleh wajib pajak. Wajib pajak juga diwajibkan untuk melaporkan secara teratur jumlah pajak yang terutang dan yang telah dibayar sebagaimana ditentukan dalam peraturan perundang-undagan perpajakan.

3. Withholding Tax System. Sistem pemungutan pajak yang memberi wewenang kepada pihak ketiga yang ditunjuk untuk menentukan besaran pajak terutang sesuai dengan peraturan perundang-undangan perpajakan yang berlaku. Penunjukkan pihak ketiga dilakukan sesuai peraturan perundangundangan perpajakan, keputusan presiden, dan peraturan lainnya untuk memotong serta memungut pajak, menyetor, dan mempertanggungjawabkan melalui sarana perpajakan yang tersedia.

\section{Teori Hak}

Teori hak merupakan pendekatan yang paling banyak dipakai untuk mengevaluasi baik buruk suatu perbuatan atau perilaku. Teori hak merupakan suatu aspek dari teori deontologi, karena hak berkaitan erat dengan kewajiban. Dalam teori etika, dahulu etika lebih ditekankan pada kewajiban, namun sekarang sudah mengalami perubahan di mana hak paling banyak disoroti. Walaupun teori hak berakar dalam teori deontologi, namun sekarang teori hak mendapatkan suatu identitas tersendiri dan karena itu pantas dibahas tersendiri pula.

Hak didasarkan atas pemikiran bahwa martabat semua manusia itu sama, baik seorang pejabat, atau bangsawan, ataupun rakyat biasa semuanya sama dan tidak boleh diperlakukan dengan cara yang berbeda. Teori hak sekarang begitu populer karena dinilai cocok untuk mengevaluasi baik buruk suatu perbuatan atau perilaku. Karena itu manusia siapa pun itu tidak pernah boleh diperlakukan semata-mata sebagai sarana demi tercapainya suatu tujuan lain.

Gambar 2.1

Model Penelitian

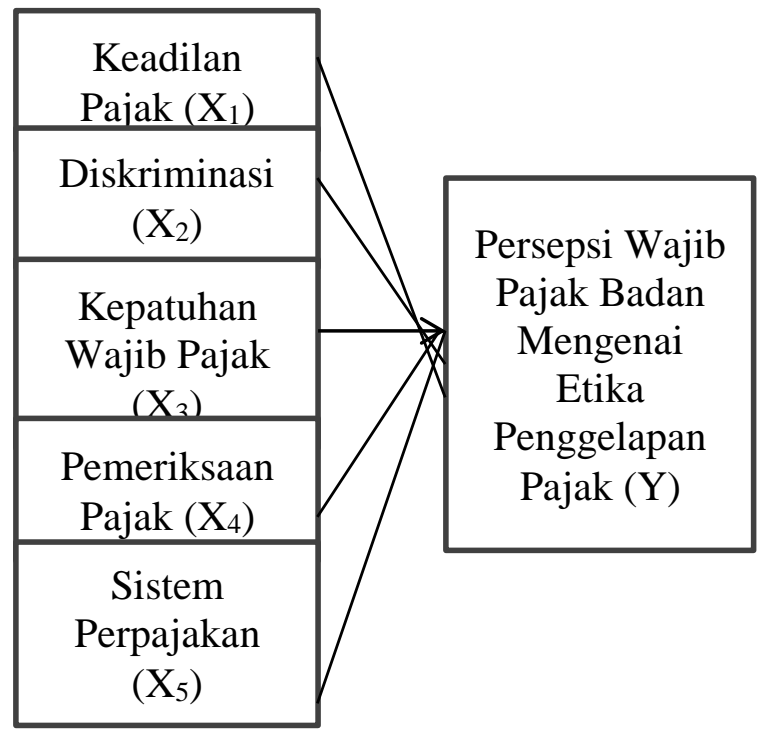

\section{PERUMUSAN HIPOTESIS}

\section{Hubungan Keadilan Pajak Terhadap Persepsi Wajib Pajak Mengenai Etika Penggelapan Pajak}

Dalam konteks perpajakan, keadilan pajak mengacu pada manfaat yang telah wajib pajak terima dari pemerintah atas pembayaran pajak yang telah dibayar oleh wajib pajak. Mengacu pada teori etika yaitu teori hak, keadilan pajak sangat penting karena menyangkut hak wajib pajak. Pemerintah dikatakan adil apabila uang pajak yang 
dibayarkan oleh wajib pajak digunakan sebagaimana mestinya, yaitu untuk pengeluaran negara, tidak untuk kepentingan pribadi pemerintah, serta pemerintah juga dapat dikatakan adil apabila pengenaan dan pemungutan pajak diperlakukan dengan sama, hal ini akan terlihat dari undang-undang pajak yang telah disusun dan yang telah dilaksanakan (Suminarsasi, 2011). Dalam penerapan pajak digunakan sebagai sumber penerimaan negara yang sangat penting, yang berarti bahwa pemerintah juga harus berusaha untuk mencapai kondisi di mana masyarakat secara luas dapat juga merasakan keadilan dalam penerapan undang-undang dan ketentuan perpajakan (Ningsih, 2014).

Keadilan pajak sangat penting diterapkan agar dapat mempengaruhi sikap wajib pajak dalam melaksanakan kewajiban perpajakan. Hasil penelitian yang dilakukan oleh Hasibuan (2014) dan Rahman (2013) menunjukkan keadilan pajak mempengaruhi persepsi wajib pajak mengenai etika penggelapan pajak secara positif, yaitu jika semakin rendah keadilan yang berlaku, maka wajib pajak akan cenderung untuk tidak patuh terhadap peraturan. Ketidakpatuhan akan berakibat pada wajib pajak yang enggan membayar pajak, sehingga wajib pajak akan mempunyai persepsi bahwa penggelapan pajak merupakan tindakan yang etis untuk dilakukan. Maka hipotesis pertama dapat dirumuskan sebagai berikut:

$\mathrm{H}_{1}$ : Keadilan pajak berpengaruh positif terhadap persepsi wajib pajak badan mengenai etika penggelapan pajak.

\section{Hubungan Diskriminasi Terhadap Persepsi Wajib Pajak Mengenai Etika Penggelapan Pajak}

Dalam bidang perpajakan, diskriminasi merupakan kondisi di mana pemerintah membeda-bedakan perlakuan terhadap setiap wajib pajak yang satu dengan yang lain. Mengacu pada teori hak, wajib pajak berhak memperoleh keadilan dalam penerapan undang-undang perpajakan. Pemerintah dapat dikatakan melakukan diskriminasi apabila kebijakan yang telah diterapkan hanya dapat menguntungkan pihak tertentu saja, dan di sisi lain ada pihak yang merasa dirugikan. Diskriminasi dapat menyebabkan wajib pajak merasa diperlakukan secara tidak adil akibat dari penerapan yang memihak atau peraturan perpajakan yang diterapkan secara tidak baik (Hasibuan, 2014). Jika semakin banyak peraturan yang dianggap sebagai bentuk diskriminasi, maka hal tersebut akan mempengaruhi sikap wajib pajak untuk tidak setuju dengan kebijakan yang berlaku.

Diskriminasi ada karena suatu keadaan tertentu, misalnya terdapat hubungan istimewa antara fiskus dengan wajib pajak yang menyebabkan wajib pajak melakukan kecurangan seperti memperkecil atau tidak membayar pajak (Zuliyanti, 2017). Hasil penelitian yang dilakukan oleh Dewi (2017) dan Hasibuan (2014) menunjukkan diskriminasi mempengaruhi persepsi wajib pajak mengenai etika penggelapan pajak secara positif, yaitu semakin banyak peraturan perpajakan yang dianggap sebagai bentuk diskriminasi yang merugikan, maka wajib pajak akan cenderung untuk tidak patuh terhadap peraturan. Ketidakpatuhan dapat berakibat pada wajib pajak yang enggan membayar pajak, sehingga wajib pajak akan mempunyai persepsi bahwa penggelapan pajak merupakan tindakan yang cenderung etis untuk dilakukan. Maka hipotesis kedua dapat dirumuskan sebagai berikut:

$\mathrm{H}_{2}$ : Diskriminasi berpengaruh positif terhadap persepsi wajib pajak badan mengenai etika penggelapan pajak

\section{Hubungan Kepatuhan Wajib Pajak Terhadap Persepsi Wajib Pajak Mengenai Etika Penggelapan Pajak}

Sistem perpajakan di Indonesia menganut self assessment system, di mana dalam sistem ini menuntut kepatuhan wajib pajak yang tinggi, yaitu kepatuhan dalam memenuhi serta melaksanakan kewajiban perpajakan sesuai dengan ketentuan peraturan perundang-undangan perpajakan. Menurut Fatimah (2016) kepatuhan memenuhi kewajiban perpajakan secara sukarela merupakan kunci dalam keberhasilan self assessment system, sehingga kepatuhan wajib pajak sangatlah diperlukan, dengan tujuan untuk mengoptimalisasi penerimaan pajak.

Mengacu pada teori hak, wajib pajak memiliki kewajiban untuk membayar pajak sesuai dengan pajak terutang. Apabila wajib pajak sudah memenuhi kewajiban untuk membayar pajak maka wajib pajak berhak memperoleh hak untuk merasakan manfaat dari uang pajak seperti pembangunan jalan raya, tunjangan kesehatan, serta pendidikan (Hasibuan, 2014). Keterkaitan antara kepatuhan wajib pajak dengan persepsi wajib pajak mengenai etika penggelapan pajak yaitu wajib pajak yang memiliki tingkat kepatuhan 
yang tinggi cenderung untuk tidak melakukan penggelapan pajak. Kepatuhan wajib pajak yang baik dapat dilihat dari keteraturan wajib pajak untuk membayar pajak. Penelitian yang dilakukan oleh Fatimah (2017) dan Hasibuan (2014) menunjukkan bahwa kepatuhan wajib pajak berpengaruh negatif terhadap persepsi wajib pajak mengenai etika penggelapan pajak. Maka hipotesis ketiga dapat dirumuskan sebagai berikut:

$\mathrm{H}_{3}$ : Kepatuhan wajib pajak berpengaruh negatif terhadap persepsi wajib pajak badan mengenai etika penggelapan pajak.

\section{Hubungan Pemeriksaan Pajak Terhadap Persepsi Wajib Pajak Mengenai Etika Penggelapan Pajak}

Menurut Sari (2013:228), pemeriksaan pajak adalah serangkaian kegiatan untuk mencari, mengumpulkan, dan mengelola data untuk menguji kepatuhan kewajiban perpajakan berdasarkan ketentuan perundangundangan perpajakan. Pemeriksaan pajak dilakukan agar dapat mendeteksi kemungkinan kecurangan yang dilakukan oleh wajib pajak. Fiskus sangat berperan penting akan mengurangi penggelapan pajak dengan melakukan pemeriksaan secara berkala. Pemeriksaan pajak dapat digunakan sebagai alat evaluasi penerapan di bidang perpajakan yang harus dapat diaplikasikan secara baik untuk mengurangi perilaku penggelapan pajak. Maka semakin rutin pemeriksaan pajak yang dilakukan oleh fiskus, wajib pajak akan mempunyai persepsi bahwa penggelapan pajak merupakan tindakan yang tidak etis untuk dilakukan. Hasil penelitian yang dilakukan Hasibuan (2014) dan Rahman (2013) menunjukkan bahwa pemeriksaan pajak berpengaruh negatif terhadap persepsi wajib pajak mengenai etika penggelapan pajak. Maka hipotesis keempat dapat dirumuskan sebagai berikut:

$\mathrm{H}_{4}$ : Pemeriksaan pajak berpengaruh negatif terhadap persepsi wajib pajak badan mengenai etika penggelapan pajak

\section{Hubungan Sistem Perpajakan Terhadap Persepsi Wajib Pajak Mengenai Etika Penggelapan Pajak}

Sistem pemungutan pajak merupakan salah satu elemen penting dalam menunjang keberhasilan pemungutan pajak di suatu negara. Indonesia menganut self assessment system, di mana wajib pajak diberi wewenang untuk menghitung, menyetor, dan melapor sendiri pajak terutang. Fiskus betugas untuk mengawasi pelaksanaan dengan melakukan pemeriksaan atas kepatuhan wajib pajak. Dengan berlaku sistem pemungutan pajak yaitu self assessment system, wajib pajak dituntut sadar, jujur, mau, dan disiplin dalam melaksanakan peraturan perpajakan, tetapi justru self assessment system dapat menciptakan peluang bagi wajib pajak untuk melakukan penggelapan pajak, karena wajib pajak diberikan wewenang untuk melaksanakan kewajiban perpajakan.

Pengaplikasian sistem perpajakan menjadi sesuatu hal yang sangat penting. Semakin baik sistem perpajakan, akan meningkatkan kepercayaan wajib pajak terhadap pemerintah, sehingga wajib pajak akan cenderung semakin patuh dalam melakukan kewajiban perpajakan. Dengan sistem perpajakan yang baik akan memberikan kemudahan dan mendorong kemauan wajib pajak dalam melakukan kewajiban perpajakan, sehingga diharapkan kepatuhan wajib pajak dapat meningkat seiring dengan dipermudah cara pembayaran dan pelaporan pajak agar dapat mengurangi tindakan penggelapan pajak. Hasil penelitian yang dilakukan Rahman (2013) dan Zuliyanti (2017) menunjukkan bahwa sistem perpajakan berpengaruh terhadap persepsi wajib pajak mengenai penggelapan pajak. Maka hipotesis kelima dapat dirumuskan sebagai berikut:

$\mathrm{H}_{5}$ : Pemeriksaan pajak berpengaruh negatif terhadap persepsi wajib pajak badan mengenai etika penggelapan pajak

\section{METODE PENELITIAN}

Jenis penelitian dalam penelitian ini yaitu penelitian survei, di mana penelitian survei merupakan penelitian kuantitatif dengan menggunakan pernyataan terstruktur yang berupa kuesioner. Kuesioner yang dibagikan merupakan kuesioner yang sama pada setiap wajib pajak badan, kemudian semua jawaban yang diperoleh dari kuesioner dicatat, diolah, dan dianalisis untuk mengetahui determinan persepsi mengenai etika penggelapan pajak pada wajib pajak badan yang terdaftar di KPP Pratama Purwakarta (Abrahams, 2016). Populasi dalam penelitian ini yaitu wajib pajak badan yang terdaftar di Kantor Pelayanan Pajak (KPP) Pratama Purwakarta. Populasi dalam penelitian ini berjumlah 7.942 wajib pajak badan yang terdaftar di KPP Pratama Purwakarta. Penentuan ukuran sampel dalam 
penelitian ini dilakukan dengan menggunakan rumus Slovin sebagai berikut:

$$
\begin{gathered}
n=\frac{N}{1+N e^{2}} \\
n=\frac{7.942}{1+7.942(0.1)^{2}}
\end{gathered}
$$

$n=98.76$ sampel responden, dibulatkan 100 sampel responden

Keterangan:

$\mathrm{n}$ : jumlah sampel

$\mathrm{N}$ : jumlah populasi

e : persentase kesalahan sampel, $a=0.1(10 \%)$

Berdasarkan perhitungan rumus slovin dengan populasi yang berjumlah 7.942 wajib pajak badan dengan batas toleransi kesalahan sebesar $10 \%$ maka didapat sampel penelitian sebanyak 100 responden. Jenis data yang digunakan dalam penelitian ini yaitu data primer. Data primer merupakan data yang diperoleh secara langsung dari pihak pertama, dalam hal ini pihak pertama merupakan responden penelitian yaitu wajib pajak badan yang terdaftar di KPP Pratama Purwakarta. Data yang diberikan merupakan data yang sesuai dengan tujuan penelitian (Sekaran \& Bougie, 2003:113). Berdasarkan jenis data, peneliti menggunakan data primer. Metode yang digunakan dalam penelitian yaitu metode survei dengan menggunakan kuesioner. Penyebaran kuesioner dilakukan kepada wajib pajak badan yang terdaftar di KPP Pratama Purwakarta.

\section{Metode Analisis Data}

Metode statistik yang digunakan untuk pengujian hipotesis pada penelitian ini yaitu Partial Least Square (PLS), yang dilakukan dengan bantuan program SmartPLS versi 2.0 M3. Analisis data menggunakan PLS dilakukan dengan menganalisis outer model dan inner model. Outer model digunakan untuk menilai validitas dan reliabilitas alat ukur, sedangkan inner model digunakan untuk memprediksi hubungan kausalitas antar variabel laten (Jogiyanto \& Abdillah, 2009:57).

\section{Analisis Outer Model}

Uji validitas bertujuan untuk mengukur valid atau tidak suatu kuesioner untuk digunakan dalam penelitian. Peneliti menyebar kuesioner secara langsung kepada wajib pajak badan yang terdaftar di KPP Pratama Purwakarta. Pilot Test (dalam rangka uji validitas) dilakukan dengan tujuan untuk mengetahui apakah kuesioner yang disusun telah valid dan reliabel. Dalam PLS suatu kuesioner dianggap valid dengan melihat hasil dari:

1. Validitas Konvergen. Validitas Konvergen dinilai berdasarkan Average Variance Extracted (AVE) untuk pertanyaan yang berkaitan dengan kontruk tersebut. Nilai AVE yang dapat diterima adalah $>0,5$ atau serta nilai outer loading harus $>0,5$.

2. Validitas Diskriminan. Nilai ini merupakan nilai cross loading faktor yang berguna untuk mengetahui apakah konstruk memiliki diskriminan yang memadai yaitu dengan cara membandingkan nilai loading pada konstruk yang dituju harus lebih besar dibandingkan dengan nilai loading dengan konstruk yang lain.

Setelah pengujian validitas konvergen dan validitas diskriminan dilakukan pada setiap kontruk, maka langkah selanjutnya yaitu melakukan pengujian reliabilitas. Pengujian reliabilitas dapat diukur dengan melihat nilai cronbach's alpha dan nilai composite reliability. Nilai cronbach's alpha harus >0,6 dan nilai composite reliability harus $>0,7$.

\section{Analisis Inner Model}

Uji $r$-square dilakukan untuk mengetahui kemampuan konstruk eksogen menjelaskan variasi pada konstruk endogen. Dalam uji $r$ square terdapat 3 kriterita nilai yaitu sebagai berikut:
1. Baik
- Nilai R2 > 0.67
2. Moderat
- Nilai R2 $>0.33$
3. Lemah
- Nilai R2 > 0.19

Uji koefisien jalur dilakukan untuk menunjukkan tingkat signifikansi dalam pengujian hipotesis (Jogiyanto \& Abdillah, 2009:62). Uji koefisien jalur dapat diperoleh dengan prosedur Bootstraping dalam PLS. Hasil uji koefisien jalur dengan melihat hasil thitung yang dibandingkan dengan t-tabel. Jika nilai t-hitung lebih besar dari nilai t-tabel (1.96) dengan taraf signifikansi ( $\alpha 5 \%)$ maka nilai estimasi koefisien jalur tersebut ialah signifikan, dan hal tersebut mengindikasikan bahwa hipotesis dapat diterima.

\section{HASIL DAN PEMBAHASAN \\ Pengaruh Keadilan Pajak Terhadap Persepsi Wajib Pajak Mengenai Etika Penggelapan Pajak}

Hipotesis pertama $\left(\mathrm{H}_{1}\right)$ yaitu keadilan pajak tidak berpengaruh terhadap persepsi wajib pajak badan mengenai etika penggelapan pajak. Berdasarkan hasil pengujian hipotesis, variabel keadilan pajak memiliki nilai t-ststistik 
adalah 0.925803 atau $\leq 1,96$ dengan nilai koefisien positif 0.138957 . Hal ini berarti bahwa keadilan pajak tidak berpengaruh terhadap persepsi wajib pajak mengenai etika penggelapan pajak.

Yang berarti bahwa semakin tinggi keadilan yang dilakukan oleh pemerintah, hal tersebut tidak memberikan pengaruh terhadap persepsi wajib pajak mengenai etika penggelapan pajak. Berarti bahwa penggelapan pajak dapat dikatakan perilaku yang etis atau tidak etis tidak dipengaruhi oleh faktor keadilan pajak. Hasil penelitian ini sejalan dengan penelitian Zuliyanti (2017) yang menunjukkan bahwa tidak terdapat pengaruh keadilan pajak dengan persepsi wajib pajak badan mengenai etika penggelapan pajak, karena persepsi wajib pajak badan di KPP Pratama Surabaya Rungkut menganggap bahwa penggelapan pajak merupakan tindakan yang tidak etis untuk dilakukan tanpa dipengaruhi oleh faktor keadilan pajak. Disisi lain hasil penelitian ini berbeda dengan hasil penelitian sebelumnya yang dilakukan oleh Hasibuan (2014) dan Rahman (2013) yang menunjukkan bahwa keadilan pajak mempunyai pengaruh positif terhadap persepsi wajib pajak badan mengenai etika penggelapan pajak.

\section{Pengaruh Diskriminasi Terhadap Persepsi Wajib Pajak Mengenai Etika Penggelapan Pajak}

Hipotesis kedua $\left(\mathrm{H}_{2}\right)$ diskriminasi tidak berpengaruh terhadap persepsi wajib pajak badan mengenai etika penggelapan pajak. Berdasarkan hasil pengujian hipotesis, variabel diskriminasi memiliki nilai t-ststistik adalah 0.842965 atau $\leq 1,96$ dengan nilai koefisien negatif -0.118314. Hal ini berarti bahwa diskriminasi tidak berpengaruh terhadap persepsi wajib pajak mengenai etika penggelapan pajak.

Yang berarti bahwa setinggi apapun diskriminasi yang dilakukan, hal tersebut tidak memberikan pengaruh terhadap persepsi wajib pajak mengenai etika penggelapan pajak. Berarti bahwa penggelapan pajak dapat dikatakan perilaku yang etis atau tidak etis tanpa dipengaruhi oleh faktor diskriminasi. Hasil penelitian ini sejalan dengan penelitian Widjaja (2017) yang menjelaskan bahwa diskriminasi tidak berpengaruh terhadap persepsi wajib pajak badan mengenai etika penggelapan pajak, karena persepsi wajib pajak badan di KPP Pratama Bitung menganggap bahwa penggelapan pajak merupakan perilaku yang tidak etis tanpa dipengaruhi oleh faktor diskriminasi. Disisi lain hasil penelitian ini berbeda dengan hasil penelitian sebelumnya yang dilakukan oleh Hasibuan (2014) dan Dewi (2017) yang menunjukkan bahwa diskriminasi mempunyai pengaruh positif terhadap persepsi wajib pajak badan mengenai etika penggelapan pajak.

Pengaruh Kepatuhan Wajib Pajak Terhadap Persepsi Wajib Pajak Mengenai Etika Penggelapan Pajak

Hipotesis ketiga $\left(\mathrm{H}_{3}\right)$ kepatuhan wajib pajak berpengaruh positif terhadap persepsi wajib pajak badan mengenai etika penggelapan pajak. Berdasarkan hasil pengujian hipotesis, variabel kepatuhan wajib pajak memiliki nilai t-ststistik adalah 1.996896 atau $\geq 1,96$ dengan nilai koefisien positif 0.254673 . Hal ini berarti bahwa terdapat pengaruh positif kepatuhan wajib pajak terhadap persepsi wajib pajak mengenai etika penggelapan pajak.

Menurut Siehl (2010), ada berbagai alasan wajib pajak melakukan penggelapan pajak. Salah satunya yaitu kemauan wajib pajak dalam membayar pajak yang rendah. Sistem perpajakan yaitu self assessment system, sangat menuntut kepatuhan wajib pajak yang besar, yaitu kepatuhan dalam memenuhi serta melaksanakan kewajiban perpajakan. Kepatuhan wajib pajak sangatlah diperlukan, dengan tujuan untuk mengoptimalisasi penerimaan pajak. Menurut Hasibuan (2014) kepatuhan wajib pajak dapat diukur dengan sejauh mana wajib pajak memiliki kesadaran untuk melaksanakan kewajiban pajak dan tidak ingin untuk melakukan penggelapan pajak. Semakin rendah kepatuhan wajib pajak maka tingkat penggelapan pajak akan cenderung meningkat yang membuat wajib pajak mempunyai persepsi bahwa penggelapan pajak merupakan tindakan yang cenderung etis untuk dilakukan. Hasil penelitian ini sejalan dengan penelitian yang dilakukan oleh Zuliyanti (2017) dan Putri (2017) yang menunjukkan bahwa terdapat pengaruh positif kepatuhan wajib pajak terhadap persepsi wajib pajak mengenai etika penggelapan pajak. Disisi lain hasil penelitian ini berbeda dengan hasil penelitian sebelumnya yang dilakukan oleh Fatimah (2017) dan Hasibuan (2014) menunjukkan bahwa kepatuhan wajib pajak berpengaruh negatif terhadap persepsi wajib pajak mengenai etika penggelapan pajak. 


\section{Pengaruh Pemeriksaan Pajak Terhadap Persepsi Wajib Pajak Mengenai Etika Penggelapan Pajak}

Hipotesis keempat $\left(\mathrm{H}_{4}\right)$ pemeriksaan pajak tidak berpengaruh terhadap persepsi wajib pajak mengenai etika penggelapan pajak. Berdasarkan hasil pengujian hipotesis, variabel pemeriksaan pajak memiliki nilai t-ststistik adalah 1.579779 atau $\leq 1,96$ dengan nilai koefisien positif 0.092688 . Hal ini berarti bahwa pemeriksaan pajak tidak berpengaruh terhadap persepsi wajib pajak mengenai etika penggelapan pajak.

Yang berarti bahwa semakin tinggi pemeriksaan pajak yang dilakukan oleh pemerintah, hal tersebut tidak memberikan pengaruh terhadap persepsi wajib pajak mengenai etika penggelapan pajak. Berarti bahwa penggelapan pajak dapat dikatakan perilaku yang etis atau tidak etis tanpa dipengaruhi oleh faktor pemeriksaan pajak.. Hasil penelitian ini sejalan dengan penelitian Zuliyanti (2017) yang menunjukkan bahwa tidak terdapat pengaruh pemeriksaan pajak terhadap persepsi wajib pajak badan mengenai etika penggelapan pajak, karena persepsi wajib pajak badan di KPP Pratama Surabaya Rungkut menganggap bahwa penggelapan pajak merupakan tindakan yang tidak etis untuk dilakukan tanpa dipengaruhi oleh faktor pemeriksaan pajak. Disisi lain hasil penelitian ini berbeda dengan hasil penelitian sebelumnya yang dilakukan oleh Hasibuan (2014) dan Rahman (2013) yang menunjukkan bahwa pemeriksaan pajak mempunyai pengaruh negatif terhadap persepsi wajib pajak mengenai etika penggelapan pajak.

\section{Pengaruh Sistem Pajak Terhadap Persepsi Wajib Pajak Mengenai Etika Penggelapan Pajak}

Hipotesis kelima $\left(\mathrm{H}_{5}\right)$ yaitu sistem perpajakan berpengaruh positif terhadap persepsi wajib pajak mengenai etika penggelapan pajak. Berdasarkan hasil pengujian hipotesis, variabel sistem perpajakan memiliki nilai t-ststistik adalah 2.908000 atau $\square 1,96$ dengan nilai koefisien positif 0.366459 . Hal ini berarti bahwa terdapat pengaruh positif sistem perpajakan terhadap persepsi wajib pajak mengenai etika penggelapan pajak.

Sistem perpajakan yang baik akan memberi kemudahan dalam memenuhi kewajiban perpajakan (www.pajak.go.id). Dengan sistem pemungutan pajak yaitu self assessment system, wajib pajak dituntut sadar, jujur, mau, dan disiplin dalam membayar pajak, tetapi justru self assessment system dapat menciptakan peluang bagi wajib pajak dalam melakukan penggelapan pajak, karena wajib pajak diberi wewenang untuk melaksanakan kewajiban perpajakan sendiri. Jika semakin rendah pengawasan terhadap sistem pajak, maka kepatuhan wajib pajak akan cenderung untuk menurun, yang berarti bahwa kecenderungan wajib pajak melakukan penggelapan pajak akan semakin tinggi. Hasil penelitian ini sejalan dengan penelitian yang dilakukan oleh Zuliyanti (2017) dan Putri (2017) menunjukkan bahwa sistem perpajakan memiliki pengaruh positif terhadap persepsi wajib pajak mengenai etika penggelapan pajak. Disisi lain hasil penelitian ini berbeda dengan hasil penelitian sebelumnya yang dilakukan oleh Fatimah (2017) yang menunjukkan bahwa tidak terdapat pengaruh sistem perpajakan terhadap persepsi wajib pajak mengenai etika penggelapan pajak.

\section{SIMPULAN DAN SARAN}

Berdasarkan hasil pengolahan data kesimpulan yang dapat diambil dalam penelitian ini yaitu, keadilan pajak, diskriminasi, dan pemeriksaan pajak tidak mempunyai pengaruh terhadap persepsi wajib pajak badan mengenai etika penggelapan pajak, sedangkan kepatuhan wajib pajak dan sistem perpajakan mempunyai pengaruh positif terhadap persepsi wajib pajak badan mengenai etika penggelapan pajak. Penelitian ini masih terdapat beberapa keterbatasan, adapun keterbatasan dari penelitian ini yaitu, (1) responden penelitian ini terbatas hanya menggunakan wajib pajak badan di Kota Purwakarta, sehingga kurang mewakili dari keseluruhan wajib pajak di Kota Purwakarta, (2) pernyataan-pernyataan dalam kuesioner masih berupa pertanyaan tertutup, sehingga responden tidak dapat menyalurkan pendapat sesuai dengan persepsi responden. Saran yang dapat diberikan peneliti untuk peneliti selanjutnya sebaiknya memperluas responden pada wajib pajak orang pribadi yang memiliki kegiatan usaha dan menggunakan metode penelitian selain survei, misalnya wawancara untuk memperoleh hasil penelitian yang lebih baik. 


\section{REFERENSI}

Bertens, K. (2000). Pengantar Etika Bisnis. Yogyakarta: Penerbit Kanisius.

Bugin, B. (2013). Metode Penelitian Sosial dan Ekonomi: Format-format Kuantitatif dan Kualitatif Untuk Studi Sosiologi, Kebijakan, Publik, Komunikasi, Manajemen, dan Pemasara Edisi Pertama. Jakarta: Kencana Prenada Media.

Danandjaja, J. (2003). Diskriminasi Terhadap Minoritas Masih Merupakan Masalah Aktual di Indonesia Sehingga Perlu Ditanggulangi Segera. Universitas Indonesia.

Faradiza, S. A. (2018). Persepsi Keadilan, Sistem Perpajakan, Dan Diskriminasi Terhadap Etika Penggelapan Pajak. Jurnal Ilmu Akuntansi, 11(1), 53-74.

Fatimah, S., \& Wardani. D. K. (2017). Faktorfaktor yang Mempengaruhi Penggelapan Pajak di Kantor Pelayanan Pajak Pratama Temanggung. Jurnal Akuntansi Dewantara, 1(1).

Greenberg, J., \& Baron, R. A. (2003). Perilaku Organisasi. Jakarta: Penerbit Prentice Hall.

Hasibuan, R. P. S. (2014). Faktor-Faktor Yang Mempengaruhi Persepsi Wajib Pajak Mengenai Etika Penggelapan Pajak (Tax Evasion) (Studi Empiris Di KPP Pratama Medan-Polonia). (Skripsi, Universitas Sumatera Utara). Diakses dari:

http://repository.usu.ac.id/handle/12345 6789/44120t.

Hussein, A. S. (2015). Penelitian Bisnis dan Manajemen Menggunakan Partial Least Squares (PLS) dengan SmartPLS 3.0. Universitas Brawijaya.

Indriyani, M., Nurlaela, S., \& Wahyuningsih, E. M. (2016). Pengaruh Keadilan, Sistem Perpajakan, Diskriminasi, dan Kemungkinan Terdeteksinya Kecurangan Terhadap Persepsi Wajib
Pajak Orang Pribadi Mengenai Perilaku

Tax Evasion. Seminar Nasional IENACO.

Ilyas, W. B. \& Priantara, D. (2015). Akuntansi Perpajakan. Jakarta: Mitra Wacana Media.

Jogiyanto, H. M., \& Abdillah, W. (2009). Konsep dan Aplikasi PLS untuk Penelitian Empiris. Yogyakarta: BPFE

Jogiyanto, H. M. (2017). Metodologi Penelitian Bisnis Salah Kaprah dan PengalamanPengalaman. Edisi Keenam. Yogyakarta: BPFE

Laporan Tahunan Direktorat Jenderal Pajak. Diakses dari http://www.pajak.go.id/laporantahunan-djp.

Mardiasmo. (2013). Perpajakan Edisi Revisi. Yogyakarta: Andi.

McGee, R. W. (2005). Tree Views on The Ethics of Tax Evasion. Journal of Business Ethics 2006, 15-35.

McGee, R. W., Simon \& Annie. (2008). A Comparative Study on Perceived Ethics of Tax Evasion: Hong Kong vs The United Stated. Journal of Business Ethics 2008, 147-158.

Mujiyanti., Rohmawati, F. R., \& Ririn, W. H. (2017). Determinan Persepsi Mengenai Etika Atas Penggelapan Pajak (Tax Evasion). Riset Akuntansi dan Keuangan Indonesia, 3(1).

Nurmatu, Safri. (2005). Pengantar Perpajakan. Jakarta: Granit.

Ningsih, D. N. C. \& Pusposari, D. (2014). Determinan Persepsi Mengenai Etika Atas Penggelapan Pajak (Tax Evasion) (Studi Pada Mahasiswa Jurusan Akuntansi Fakultas Ekonomi dan Bisnis Universitas Brawijaya). Jurnal Ilmiah Mahasiswa Fakultas Ekonomi dan Bisnis Universitas Brawijaya, 3(1).

Padiat. (2008). Pemeriksaan Pajak, Edisi kedua. Jakarta: Mitra Wacana Media.

Pareek, U. (2001). Perilaku Organisasi: Pedoman Ke arah Pemahaman Proses Komunikasi Antar Pribadi dan Motivasi Kerja. Jakarta: Pustaka Binaman Presindo.

Putri, H. (2017). Pengaruh Sistem Perpajakan, Diskriminasi, Kepatuhan, Dan Pengetahuan Perpajakan Terhadap Persepsi Wajib Pajak Mengenai Etika Penggelapan Pajak (Studi Empiris Pada Wajib Pajak Orang Pribadi Di Wilayah 
Kota Pekanbaru). Jurnal Online Mahasiswa Fakultas Ekonomi Universitas Riau, 4(1).

Rahayu, S. K. (2013). Perpajakan Indonesia: Konsep dan Aspek Formal. Yogyakarta: Graha ilmu.

Rahman, I. S. (2013). Pengaruh Keadilan, Sistem Perpajakan, Diskriminasi, Dan Kemungkinan Terdeteksinya Kecurangan Terhadap Persepsi Wajib Pajak Mengenai Etika Penggelapan Pajak (Tax Evasion). (Skripsi, Universitas Islam Negeri Syarif Hidayatullah).

Resmi, S. (2016). Perpajakan: Teori dan Kasus. Edisi 9 Buku 1. Jakarta: Salemba Empat.

Robbins, S. P., \& Judge, T, A. (2015). Perilaku Organisasi, Edisi 16. Jakarta: Salemba Empat.

Sari, Diana. (2013). Konsep Dasar Perpajakan. Bandung: PT Refika Aditama.

Siahaan, Marihot Pahala. (2010). Hukum Pajak Material. Yogyakarta: Graha Ilmu.

Suandy, E. (2016). Perencanaan Pajak. Edisi 6. Jakarta: Salemba Empat.

Suminarsasi, W \& Supriyadi. (2011). Pengaruh Keadilan, Sistem Perpajakan, dan Diskriminasi Terhadap Persepsi Wajib Pajak Mengenai Etika Penggelapan Pajak (Tax Evasion). Jurnal Simposium Nasional Akuntansi.

Sekaran, U. \& Bougie, R. (2003). Reseach Method For Business: A Skill-Bulding Approach, $6^{\text {th }}$ Edition. Jihn Wiley \& Sons Ltd: Unites Kingdom.

Undang-Undang Nomor 16 Tahun 2009

Tentang Ketentuan Umum dan Tata Cara Perpajakan. Diakses dari http://www.ortax.org/ortax/?mod=atura n\&page $=$ show \&id $=13752$.

Undang-Undang Nomor 39 tahun 1999

Tentang Hak Asasi Manusia. Diakses

dari

http://referensi.elsam.or.id/2014/08/uuri-no-39-tahun-1999-tentang-hak-asasimanusia/.

Waluyo. (2014). Perpajakan Indonesia. Jakarta: Salemba Empat.

Zain, M. (2003). Manajemen Perpajakan. Jakarta: Salemba Empat.

Zulganef. (2008). Metode Penelitian Sosial dan Bisnis. Yogyakarta: Ghara Ilmu.

Zuliyanti, Try. (2017). Determinan Persepsi Wajib Pajak mengenai Etika Penggelapan Pajak (Studi pada Wajib Pajak yang
Terdaftar di Kantor Pelayanan Pajak Pratama Surabaya Rungkut). (Skripsi Tidak Terpublikasi). Jurusan Akuntansi, Universitas Brawijaya. 